\section{Knapt for den interesserte leser}

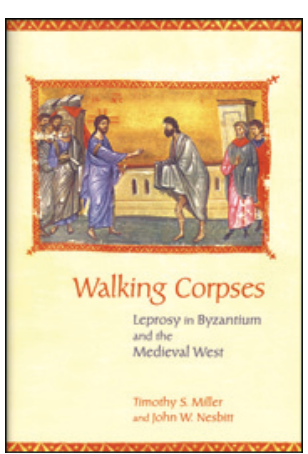

Timothy S. Miller, John W. Nesbitt

\section{Walking corpses}

Leprosy in Byzantium and the Medieval

West. 243 s, ill. Ithaca, NY: Cornell University

Press, 2014. Pris USD 35

ISBN 978-0-8014-5135-5

Forfatterne, to amerikanske historikere, har satt seg som mål å korrigere en del misforståelser som de mener gjelder lepra i middelalderens Europa. Disse misforståelsene har bl.a. Michel Foucault (1926-84) gjort seg skyldig i når han har omtalt middelalderens leprasykehus som «de fordømtes byer som spredte seg over hele Europa».

Forfatterne mener at tallrike kilder, særlig klerikale, ikke omtaler lepra som en straff for synd, men heller som et uttrykk for Guds velvilje overfor dem som er utvalgt til et evig liv i himmelen. På dette grunnlag mener forfatterne at vi må revidere vår oppfatning av leprapasientenes skjebne med hensyn til stigmatisering og segregering i middelalderen, tilsynelatende et formidabelt mål.

Først gir forfatterne en oversikt over eldre og vår tids medisinske syn på sykdommen lepra. Her gjør de en grov forenkling når de hevder at «although...physicians and scientists had begun to challenge how Galen described the human body and its illnesses, no one succeeded in replacing his explanation for leprosy until 1873, when the Norwegian scientist Gerhard Armauer Hansen identified Mycobacterium leprae as the bacteriological agent that caused leprosy». Som kilde for denne påstanden angir forfatterne Carole Rawcliffe og hennes bok Leprosy in Medieval England. Den internasjonale leprologiens bibel, Daniel Cornelius Danielssen (1815-49) og Carl Wilhelm Boecks (1808-75) monumentale verk publisert på fransk i 1848, nevnes ikke. Forløpet av ubehandlet lepra belegges med kilden Brody: Disease of the Soul; Tuberculosis and Leprosy in Antiquity».

Videre hevder forfatterne at siden 1980 kan moderne medisiner stoppe sykdomsutviklingen uten at det nevnes at allerede de tidligste sulfapreparatene hadde betydelig terapeutisk effekt og fremdeles er basismedisinen (dapsone) i våre dagers duobehandling. Det er derfor med en viss skepsis jeg nærmet meg bokens hovedanliggende: middelalderens syn på lepra.

Forfatternes naturlige utgangspunkt er tredje Moseboks omtale av de spedalske som urene. Mange kilder fra antikken viser klart at stigmatisering og segregering var utbredt. Forfatterne tar imidlertid ikke stilling til om Bibelens påbud var en årsak til, eller følge av, disse holdningene. At tredje Mosebok har hatt enorm betydning for slike holdninger etter middelalderen kan det neppe herske noen tvil om, uten at denne problemstillingen belyses.

Disse holdningene kan noe forenklet tilskrives tre ulike sett av faktorer: leprapasientenes gruoppvekkende utseende, frykten for smitte og Bibelens tredje Mosebok. At utseendet spilte en rolle kan det neppe herske noen tvil om. Forvirringen var imidlertid stor blant medisinske autoriteter når det gjaldt smitte. I henhold til den greske legen Galens (130-200) allment aksepterte sykdomslære var lepra et resultat av for mye svart galle, som igjen skyldtes forgiftet luft eller vann, men ikke smittestoff fra syke mennesker. Noen leger mente likevel at lepra var en smittsom sykdom, et syn som i stor utstrekning ble delt av folk flest.

Forfatternes budskap angår imidlertid den tredje faktor: tredje Mosebok og de tiltak oldkirken iverksatte for å motvirke Det gamle testamentets syn på spedalskhet. Med utgangspunkt i Jesu helbredelse av ti spedalske iverksatte de gamle kirkefedrene en storstilt kampanje for å sikre leprapasientene en mer human behandling. Dels dreide det seg om informasjon til de kristne menighetene rundt Middelhavet, dels bygging av leprosarier for å sikre pasientene pleie og omsorg. Ja, mer enn dette: I noen av disse institusjonene fikk pasientene anledning til å delta i ledelsen «in what was in fact an experiment in democracy under a form of constitutional government». Kjønnene var til og med likestilt. Det er mulig at dette kan ha forekommet, men formuleringen gir mistanke om at forfatterne her er blitt revet med av sin egen retorikk.

Fremstillingen gir inntrykk av at en religiøst begrunnet humanitær holdning nok kan ha forekommet, men at dette har vært det vanlige er lite sannsynlig. Forfatterne gjør således også rede for motstridende teologiske holdninger: at lepra skulle oppfattes som Guds straff for begåtte synder, og igjen med tredje Mosebok som kilde.

Samlet sett virker ikke boken overbevisende. Den er preget av tallrike gjentakelser, og en rekke feil og unøyaktigheter bidrar heller ikke til troverdighet. Anmelderen, som i sin ungdom fikk smekk over fingrene av den mektige Stanley Browne (1907-86), generalsekretær i International Leprosy Association, for å ha benyttet betegnelsen «leper» i en historisk tekst, er heller ikke særlig begeistret for å se igjen dette ordet overalt $i$ teksten - i seg selv en del av historien om stigmatisering og segregering av de spedalske. Boken kan neppe anbefales selv den mer interesserte leser.

\section{Lorentz M. Irgens}

Professor, Institutt for global helse og samfunnsmedisin Universitetet i Bergen 